\title{
THE OCCURRENCE OF ENTOMOPATHOGENIC FUNGI IN SOILS FROM CULTIVATED PERENNIAL RYEGRASS (LOLIUM PERENNE L.)
}

\author{
Roman Kolczarek ${ }^{1}$ \\ 1 Institute of Agronomy, University of Natural Sciences and Humanities, B. Prusa 14, 08-110 Siedlce, Poland, \\ e-mail: rk@uph.edu.pl
}

Received: 2014.07.20

Accepted: 2014.10.17

Published: 2015.01.02

\begin{abstract}
An important role in the agricultural agrocenosis is attributed to entomopathogenic fungi. They limit the occurrence of certain populations of soil pests and insects overwintering in the soil environment, or held in the pupation. Fungi are the only pathogens of arthropods witch have the ability to infect plant pests directly by body. However, bacteria are the largest group of microorganisms inhabiting the soil. The aim of this study was to compare the species composition and the severity of the occurrence of entomopathogenic fungi in soils of monoculture crops perennial ryegrass (Lolium perenne L.). The material consisted of soil samples taken from the experimental research conducted in two experimental stations of the Central Research Centre for Cultivar. The fungi isolated from soil insecticides using a method developed by the selective medium.
\end{abstract}

Keywords: soil, entomopathogenic fungi, perennial ryegrass (Lolium perenne L.), density of infective units.

\section{INTRODUCTION}

An important role is played by fungi agrocenosis agricultural insecticides that are capable of reducing most of the soil-dwelling pests and pests of crop plants. The main site of entomopathogenic fungi is soil, which has a huge impact on both the incidence and spread of mikoz insects. Currently, there are over 1000 known species of fungi parasitic on insects [Vanninen 1999; Bałazy 2006]. According to Gaugler [1988], it is estimated that about $90 \%$ of harmful plant arthropods spent at least part of their life cycle in the soil. Both the occurrence and the development and pathogenicity of entomopathogenic fungi in the soil are conditioned by a number of biotic and abiotic factors in the environment, as well as by agricultural and non-agricultural human activity. This is due to, among others, temperature, humidity, soil type, structure, and the manner of its use and the time of year as well as, crop species [Tkaczuk, Miętkiewski 1996]. Fungi insecticides as one of the first pathogens used in the biological control of pests on plants [Lipa 1967]. The aim of this study was to compare the species composition and the severity of the occurrence of entomopathogenic fungi in soils of monoculture crops of Lolium perenne $\mathrm{L}$.

\section{MATERIAL AND METHODS}

The material consisted of soil samples taken from the experiments on close-growing Perennial ryegrass (Lolium perenne L.) conducted in two experimental stations of the Research Centre for Cultivar Testing (COBORU) in Krzyżewo (Podlaskie Province) and Uhnin (Lublin Province). The tests were taken in two periods: spring and autumn (25.04.2012 and 28.09.2012). The experiment was carried out in two sites and concerned the assessment of yielding varieties of perennial ryegras. Detailed information on the experiment design and soil and hydrothermal conditions are shown in Table 1. The samples were taken at random from 10 points of a plot. The soil was collected using canes to a depth of $15 \mathrm{~cm}$. From the material collected from the area of an untreated mixed 
and stored in plastic bags at $0-4{ }^{\circ} \mathrm{C}$. The Fungi isolated from the soil insecticides using a method developed by the selective medium [Strasser et al. 1996]. The medium is commonly used for the isolation of entomopathogenic fungi in the soil [Keller et al. 2003, Tkaczuk, 2008]. From each sample originating from a given mixed plot $2 \mathrm{~g}$ was weighed and added to $18 \mathrm{ml}$ of distilled water with addition of $0.05 \mathrm{ml}$ a solution of preparation Trithon X-100, and vigorously shaken for about 35 seconds. Then a solution of $0.1 \mathrm{ml}$ of the soil was poured and spread using a glass spatula on a surface of the substrate selectively in three petri dishes, which were repeated. The dishes were placed in incubators at $22{ }^{\circ} \mathrm{C}$ and after $8-10$ days colonies were counted for each species of fungi. The results are expressed as the number of infectious units (CFU) of entomopathogenic fungi in $1 \mathrm{~g}$ of soil.

Meteorological data for the research were obtained from the Hydrological and Meteorological Station in Krzyżewo and Uhnin. However, in order to determine the temporal variability of meteorological elements and their influence on plant growth, the coefficient of hydrothermal Sielianinov [Bac et al. 1993] and the classification Skowera and Pula [2004] were used.

The data in Table 1 show that the distribution of rainfall underwent temporal and spatial variation. Drought was observed only in Uhninie in the May $(\mathrm{K}=0.84)$. While in June, both in Krzyżewo and Uhninie the weather conditions should be considered quite humid and it was an optimum period for Krzyżewo and slightly less moisture of the Uhninie. Howewer the August was more moistly in Krzyżewo. In September, there were dry periods for both locations of Selianinov coefficient with value $\mathrm{K}=0.40$ for Krzyżewo.

\section{RESULTS}

The reaserch experiment showed that using a selective medium with meadow soils three species of entomopathogenic fungi Beauveria bassiana, Metarhizium anisopliae and Isaria fumosorosea were isolated. Species composition and density of the colony-forming units of these fungi varied depending on the variety and the place from which soil samples were derived. Spring in soils from five varieties of perennial ryegrass grown in the station COBORU in Krzyżewo recorded dominance of the fungus Metarhizium anisopliae. This species occurred in all soil samples analyzed from all varieties of perennial ryegrass (Lolium perenne L.), and worked an average of $1.5 \times 10^{3} \mathrm{CFU} \mathrm{g}^{-1}$ in $1 \mathrm{~g}$ of soil. The presence of the fungus Isaria fumosorosea reported in soils from 2 of 5 perennial ryegrass (Lolium perenne L.) grown varieties - Lacerta and Argona. Beauveria bassiana occurred only in the soil sampled from the varieties of Amarant and Argona. These fungi formed an average of $1.6 \times 10^{3} \mathrm{~g}^{-1}$ and $0.3 \times 10^{3} \mathrm{~g}^{-1}$ of colony forming units in the soils (Figure 1).

The total insecticides, most infectious units (CFU) fungiformedin soils collected from within the perennial ryegrass varieties (Lolium perenne L.) on spring: Lacerta, Amarant, Argona a minimum of Tivoli and Bah 209 (Table 2). Within the autumn in soil samples collected varieties of perennial ryegrass (Lolium perenne L.) grown in Krzyżewo included fungus Metarhizium an-

Table 1. Conditions of experimentation - Perennial ryegrass (Lolium perenne L.)

\begin{tabular}{|c|c|c|c|c|c|c|c|c|}
\hline \multirow[b]{2}{*}{ Lp. } & \multirow[b]{2}{*}{$\begin{array}{l}\text { Name of } \\
\text { place }\end{array}$} & \multirow[b]{2}{*}{$\begin{array}{l}\text { Height above } \\
\text { sea level }(\mathrm{m})\end{array}$} & \multicolumn{5}{|c|}{ Soil } & \multirow[b]{2}{*}{ Forecrop } \\
\hline & & & $\begin{array}{c}\text { Agriculture } \\
\text { Value in } 100 \text { point } \\
\text { scale IUNG }\end{array}$ & $\begin{array}{c}\text { Complex of } \\
\text { agricultural suitability }\end{array}$ & Type & Species & $\begin{array}{c}\mathrm{pH} \\
1 \mathrm{n} \mathrm{KCl}\end{array}$ & \\
\hline 1 & Krzyżewo & 130 & 70 & 4 & $A$ & gl & 6.4 & spring barley \\
\hline 2 & Uhnin & 155 & 80 & $1 z$ & M & $\mathrm{N}$ & 6.6 & meadow \\
\hline \multicolumn{9}{|c|}{ Hydrothermal coefficient of Selianinov (K) / Month } \\
\hline & & IV & V & VI & VII & VIII & IX & $x$ \\
\hline 1 & Krzyżewo & $1.63(\mathrm{fm})$ & $1.09(q d)$ & $1.83(\mathrm{fm})$ & $1.55(0)$ & $3.18(\mathrm{em})$ & $0.40(\mathrm{ed})$ & $2.27(\mathrm{~m})$ \\
\hline 2 & Uhnin & $1.06(q d)$ & $0.84(d)$ & $1.92(\mathrm{fm})$ & $0.81(d)$ & $1.25(q d)$ & $0.79(\mathrm{~d})$ & 4.90 (em) \\
\hline
\end{tabular}

Symbols: (ed) - extremely dry, (vd) - very dry, (d) - dry, (qd) - quite dry, (o) - optimal, (fm) - fairly moist, (m) - moist, (vm) - very moist, (em) - extremely moist.

Col.4; 4 - rye very good, $1 \mathrm{z}$ - grassland very good and good.

Col.5; A - podzolic; $\mathrm{M}$ - muck.

Col.6; gl - loam, $\mathrm{n}$ - deep peat with thickness of organic matter $>30 \mathrm{~cm}$. 
isopliae, which made an average of $0.9 \times 10^{3} \mathrm{~g}^{-1}$ CFU. Its presence was found in soil from all varieties of perennial ryegrass (Lolium perenne L.). Fungi Isaria fumosorosea also occurred in all tested samples of soil and constituted an average of $0.6 \times 10^{3} \mathrm{~g}^{-1} \mathrm{CFU}$ in $1 \mathrm{~g}$ of soil (Figure 1). The presence of the fungus Beauveria bassiana was observed only in soils from one cultivar perennial ryegrass (Lolium perenne L.)-Tivoli. Overall fungi insecticides formed more CFU than in the spring for fungi Isaria fumosorosea and Metarhizium anisopliae from all analyzed varieties. (Table 3). In the studied soil the samples collected from plots in the spring at the experimental station COBORU-Uhnin where cultivated varieties of perennial ryegrass 5 (Lolium perenne L.), the most infectious units fungus Beauveria bassiana made an average of $0.8 \times 10^{3} \mathrm{~g}^{-1}$, Metarhizium anisopliae $\left(0.2 \times 10^{3} \mathrm{~g}^{-1}\right)$. The fungus Isaria fumosorosea did not occur in the soil sampled within spring from any of the five varieties analyzed (Figure 2). In conclusion, the general concluded

Table 2. The density of infectious units $\left(\mathrm{CFU} \times 10^{3} \mathrm{~g}^{-1}\right)$ of entomopathogenic fungi in soil under cultivation of different varieties perennial ryegrass (Lolium perenne L.) (Krzyżewo, spring)

\begin{tabular}{|l|c|c|c|c|}
\hline \multirow{2}{*}{ Variety } & \multicolumn{4}{|c|}{ Species of fungi } \\
\cline { 2 - 5 } & $\begin{array}{c}\text { Beauveria } \\
\text { bassiana }\end{array}$ & $\begin{array}{c}\text { Isaria } \\
\text { fumosorosea }\end{array}$ & $\begin{array}{c}\text { Metarhizium } \\
\text { anisopliae }\end{array}$ & Total \\
\hline Lacerta & - & $2.7 \mathrm{e}$ & $2.2 \mathrm{~d}$ & 4.9 \\
\hline Tivoli & - & - & $3.2 \mathrm{f}$ & 3.2 \\
\hline Bah 209 & - & - & $0.5 \mathrm{bc}$ & 0.5 \\
\hline Amarant & $0.4 \mathrm{ab}$ & - & $0.7 \mathrm{c}$ & 1.1 \\
\hline Argona & $0.2 \mathrm{a}$ & $0.4 \mathrm{ab}$ & $0.7 \mathrm{c}$ & 1.3 \\
\hline
\end{tabular}

$*$ The value marked with the same letters do not differ significantly.

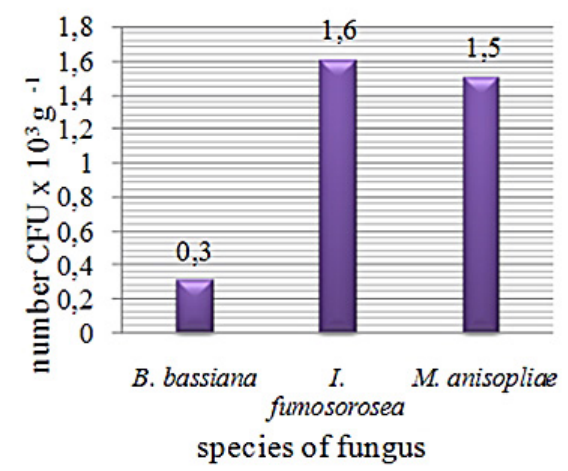

(KS) that fungi insecticides formed most infectious units in the soil sampled within the spring from growing varieties of perennial ryegrass (Lolium perenne L.) as Tivoli $\left(1.7 \times 10^{3} \mathrm{~g}^{-1}\right)$ and Argona $\left(1.2 \times 10^{3} \mathrm{~g}^{-1}\right)$ (Table 4).

The analysis of soil samples taken at the Uhnin under cultivation of different varieties perennial ryegrass (Lolium perenne L.) by autumn showed that the majority of tested samples had fungus Isaria fumosorosea. The presence of this species was observed in soils from all cultivated varieties, where created average of $1.8 \times 10^{3} \mathrm{~g}^{-1} \mathrm{CFU}$ per 1 gram of soil (Figure 2). Fungus Beauveria bassiana and Metarhizium anisopliae starred in the soil sampled from four varieties, and these fungi formed an average of $1.9 \times 10^{3} \mathrm{~g}^{-1}$ and $0.7 \times 10^{3} \mathrm{~g}^{-1}$ colony-forming units in the soils. (Figure 2). Comparing the occurrence of units of infectious fungi entomopatogennych depending on the time of soil sampling it was found that the most infectious units formed in the spring in soils under cultivation of such varieties perennial rye-

Table 3. The density of infectious units $\left(\mathrm{CFU} \times 10^{3} \mathrm{~g}^{-1}\right)$ of entomopathogenic fungi in soil under cultivation of different varieties perennial ryegrass (Lolium perenne L.) (Krzyżewo,autumn)

\begin{tabular}{|l|c|c|c|c|}
\hline \multirow{2}{*}{ Variety } & \multicolumn{4}{|c|}{ Species of fungi } \\
\cline { 2 - 5 } & $\begin{array}{c}\text { Beauveria } \\
\text { bassiana }\end{array}$ & $\begin{array}{c}\text { Isaria } \\
\text { fumosorosea }\end{array}$ & $\begin{array}{c}\text { Metarhizium } \\
\text { anisopliae }\end{array}$ & Total \\
\hline Lacerta & - & $0.2 \mathrm{a}$ & $1.2 \mathrm{~d}$ & 1.4 \\
\hline Tivoli & $0.2 \mathrm{a}$ & $0.4 \mathrm{ab}$ & $1.0 \mathrm{~d}$ & 1.6 \\
\hline Argona & - & $0.4 \mathrm{ab}$ & $1.2 \mathrm{~d}$ & 1.6 \\
\hline Amarant & - & $1.7 \mathrm{e}$ & $0.4 \mathrm{ab}$ & 2.1 \\
\hline Bah 209 & - & $0.4 \mathrm{ab}$ & $0.7 \mathrm{c}$ & 1.1 \\
\hline
\end{tabular}

* The value marked with the same letters do not differ significantly.

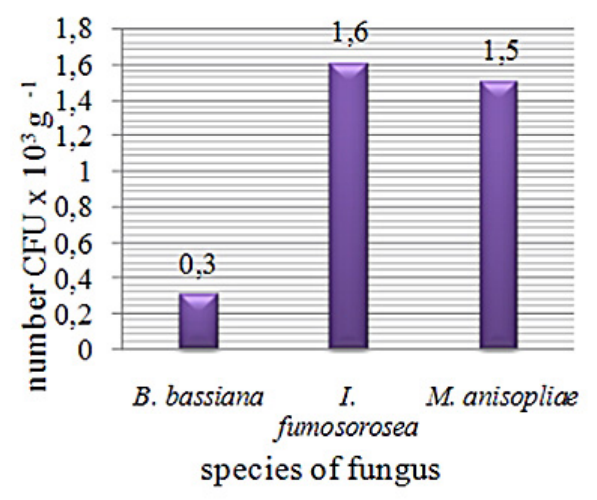

(KS)

Figure 1. Average concentration of infectious units $\left(\mathrm{CFU} \times 10^{3} \mathrm{~g}^{-1}\right)$ of individual entomopathogenic fungi in soil from cultivation of perennial ryegrass (Lolium perenne L.): Krzyżewo - (K), spring - (S), autumn - (A) 
Table 4. The density of infectious units $\left(\mathrm{CFU} \times 10^{3} \mathrm{~g}^{-1}\right)$ of entomopathogenic fungi in soil under cultivation of different varieties perennial ryegrass (Lolium perenne L.) (Uhnin, spring)

\begin{tabular}{|l|c|c|c|c|}
\hline \multirow{2}{*}{ Variety } & \multicolumn{4}{|c|}{ Species of fungi } \\
\cline { 2 - 5 } & $\begin{array}{c}\text { Beauveria } \\
\text { bassiana }\end{array}$ & $\begin{array}{c}\text { Isaria } \\
\text { fumosorosea }\end{array}$ & $\begin{array}{c}\text { Metarhizium } \\
\text { anisopliae }\end{array}$ & Total \\
\hline Argona & $1.0 \mathrm{~d}$ & - & $0.2 \mathrm{ab}$ & 1.2 \\
\hline Tivoli & $1.5 \mathrm{e}$ & - & $0.2 \mathrm{ab}$ & 1.7 \\
\hline Bah 209 & $0.7 \mathrm{bc}$ & - & - & 0.7 \\
\hline Lacerta & $0.3 \mathrm{a}$ & - & - & 0.3 \\
\hline Amarant & $0.5 \mathrm{~b}$ & - & - & 0.5 \\
\hline
\end{tabular}

* The value marked with the same letters do not differ significantly

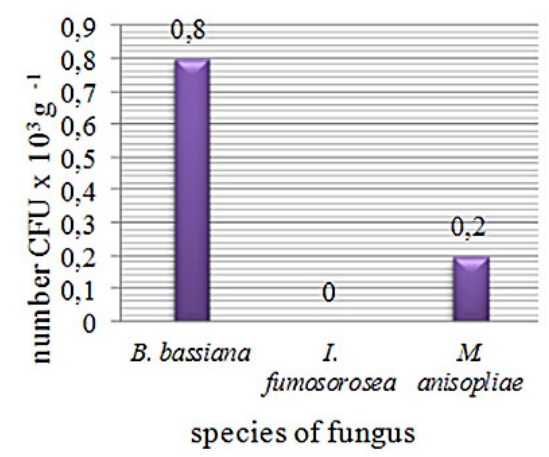

(US)
Table 5. The density of infectious units $\left(\mathrm{CFU} \times 10^{3} \mathrm{~g}^{-1}\right)$ of entomopathogenic fungi in soil under cultivation of different varieties perennial ryegrass (Lolium perenne L.) (Uhnin, autumn)

\begin{tabular}{|l|c|c|c|c|}
\hline \multirow{2}{*}{ Variety } & \multicolumn{4}{|c|}{ Species of fungi } \\
\cline { 2 - 5 } & $\begin{array}{c}\text { Beauveria } \\
\text { bassiana }\end{array}$ & $\begin{array}{c}\text { Isaria } \\
\text { fumosorosea }\end{array}$ & $\begin{array}{c}\text { Metarhizium } \\
\text { anisopliae }\end{array}$ & Total \\
\hline Argona & $2.4 \mathrm{f}$ & $0.9 \mathrm{~cd}$ & - & 3.3 \\
\hline Tivoli & $0.7 \mathrm{c}$ & $4.7 \mathrm{~h}$ & $0.7 \mathrm{c}$ & 6.1 \\
\hline Bah 209 & $3.4 \mathrm{~g}$ & $1.9 \mathrm{e}$ & $0.9 \mathrm{~cd}$ & 6.2 \\
\hline Lacerta & $0.9 \mathrm{~cd}$ & $0.7 \mathrm{c}$ & $0.9 \mathrm{~cd}$ & 2.5 \\
\hline Amarant & - & $0.7 \mathrm{c}$ & $0.4 \mathrm{~b}$ & 1.1 \\
\hline
\end{tabular}

$*$ The value marked with the same letters do not differ significantly

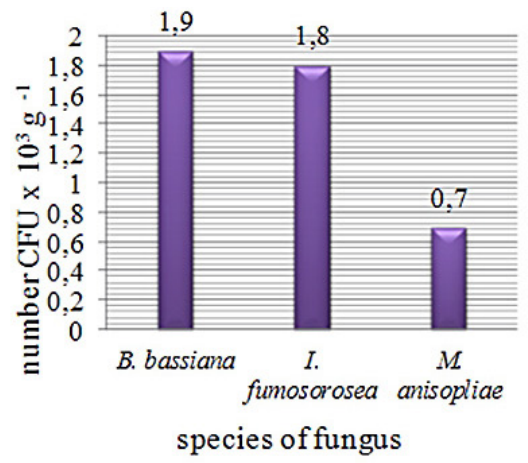

(UA)

Figure 2. Average concentration of infectious units $\left(\mathrm{CFU} \times 10^{3} \mathrm{~g}^{-1}\right)$ of individual entomopathogenic fungi in soil from cultivation perennial ryegrass (Lolium perenne L.): Uhnin - (U), spring - (S), autumn - (A)

grass (Lolium perenne L.) as Tivoli and Bah 209, $\left(6.1 \times 10^{3} \mathrm{~g}^{-1}\right.$ and $\left.6.2 \times 10^{3} \mathrm{~g}^{-1} \mathrm{CFU}\right)$ (Table 5). At the same time it was noted that the soil samples taken from the growing perennial ryegrass ( $\mathrm{Lo}$ lium perenneL.) by spring there was no presence of the fungus Isaria fumosorosea, which is found in soils collected within the autumn time.

\section{DISCUSSION}

The soils on which cultivated varieties of grasses perennial ryegrass (Lolium perenne L.) was isolated three species of entomopathogenic fungi Beauveria bassiana, Metarhizium anisopliae and Isaria fumosorosea by using a selective medium. They belonged to the most common entomopathogenic fungi in the soil environment. This is confirmed by many studies carried out by other authors [Miętkiewski et al, 1991; Bajan et al. 1997]. Species composition and density of the colony-forming units of these fungi varied depending on the variety, the seasons and the place from which soil samples were derived. The soil samples collected in Krzyżewo in both terms, from all varieties of perennial ryegrass (Lolium perenne L.), Metarhizium anisopliae fungus occurred while Isaria fumosorosea also starred in the soil sampled from all varieties of perennial ryegrass (Lolium perenne $\mathrm{L}$.), but only within autumn. Beauveria bassiana fungus and Isaria fumosorosea occurred in the collected soil sampled in the spring time only two of the five cultivated varieties of perennial ryegrass (Lolium perenne L.). In soils collected within Beauveria bassiana occurred only in soil sampled from the growing variety of Tivoli. The research by Tkaczuk [2008] has shown, that in Polish soils meadow and pasture fungus Metarhizium anisopliae, Beauveria bassiana and then Isaria fumosorosea are most common. This species seems to be characteristic of meadow and pasture environments in the UK [Chandler et al 1997], Switzerland [Keller et al 2003], and was previously listed as dominant in these soils. The soil samples collected in the spring at Station Variety Assessment in Uh- 
nin from all varieties of perennial ryegrass most colony-forming species of fungi was Beauveria bassianawas. However Isaria fumosorosea did not occurr in anyof the analyzed soil samples collected in the spring. In turn, the density of the fungus Metarhizium infectious units anisopliae was found only in soils from cultivated varieties of Lacerta and Tivioli. concentration of infectious units in soils collected within the fall was much higher for all three species of fungi. In the case of the fungus Isaria fumosorosea, it was found that the fungus occurred in the soil sampled in the period from the fall in all cultivated varieties of perennial ryegrass (Lolium perenne L.). Beauveria bassiana and Metarhizium anisopliae fall within not only occurred in the case of two varieties of perennial ryegrass (Lolium perenne L.) - Lacerta and Argona. In a similar study to Kolczarek and Jankowski [2014] the same soil habitat for various varieties of meadow fescue (Festuca pratensis) it was found that fungus Beaveria bassiana did not occur in mineral soil collected within the autumn. Other fungi were present in amounts similar to the habitats of perennial ryegrass (Lolium perenne L.). It is observed that the cause of infectious units at greater concentration of the soil which was characterized by a high content of organic matter, in contrast and light mineral soil from station COBORU Variety marks in Krzyżewo. Just as in research Ignoffo et al. [1978] who argue that clay soils are richer in entomopathogenic fungi because clay particles have an increased capacity ion, so that they have the ability to easily adsorb spores with opposite electric charge. The soil rich in organic matter are mainly rich in species that have the ability to grow in saprophytic phase. These include fungi of the genus Beauveria [Müller-Kögler, Zimmermann 1986]. Research Miętkiewski et al. [1992] indicate a higher abundance of grassland soils in fungi insecticides than adjacent soils of farmland. They compared the incidence of fungi in the soil insecticides both arable and meadow. Were studied with the cultivation of wheat fields and adjacent meadows. The authors have isolated four species of fungi Beauveria bassiana, Metarhizium anisopliae, Isaria farinosa and Isaria fumosorosea. The incidence of entomopathogenic fungi in the soils was quite varied. In the meadows fungus Metarhizium anisopliae was present, other species, besides Isaria fumosorosea, were more numerous in grassland soils. The studies on mineral soil under cultivation of perennial rye- grass (Lolium perenne L.) were also represented, including fungus Metarhizium anisopliae.

\section{CONCLUSIONS}

1. Soils under perennial ryegrass (Lolium perenne L.) contained three species of entomopathogenic fungi, that is Beauveria bassiana, Isaria fumosorosea and Metarhizium anisopliae, which were isolated using a selective medium.

2. Species composition and density of the colony-forming units varied depending on the variety, sampling date and site.

3. The fungi Beaveria bassiana and Isaria fumosorosea formed the most infectious units in organic soils and Metarhizium anisopliae in mineral soils, the number of infectious units being influenced by the soil type.

4. The fungus Beaveria bassiana formed the most infectious units (CFU) in organic soil under the variety Bah 209, Isaria fumosorosea in the autumn-sampled soil under the variety Tivoli and Metarhizium anisopliae in the spring-sampled mineral soil under Tivoli.

\section{REFERENCES}

1. Bac S., Koźmiński C., Rojek M., 1993. Agrometeorology. PWN, Warsaw, 32-33.

2. Bałazy S. 2006. Diagnosis and attempt to estimate the role of entomopathogenic fungi in the stands. Studies and Research Centre for Education Natural Sciences and Forest. 4 (14), 154-165.

3. Bajan C., Kmitowa K. 1997. Thirty years studies on entomopathogenic fungi in the Institute of Ecology, PAS. Pol. Ecol. Stud., 23(3-4), 133-154.

4. Chandler D., Hay D., Reid A.P., 1997. Sampling and occurrence of entomopathogenic fungi and nematodes in UK soils. Appl Soil Ecol. 5, 133-141.

5. Gaugler R. 1988. Ecological consideration In the Biol.Contr. of soilinhabiting insects with entomopathogenic nematodes. Agric., Ecosystem. Environ. 24, 351-361.

6. Ignoffo C.M., Garcia C., Hostetter D.L., Pinnel R.E. 1978. Stability of conidia of entomopathogenic fungus Nomuraea rileyi in a soil. J. Invertebr. Pathol. 28, 259-262.

7. Keller S., Kessler P., Schweizer C. 2003. Distribution of insect pathogenic soil fungi in Switzerland with special reference is Beauveria brongniartii and Matarhizium anisopliae. Biocontrol, 48, 307-319. 
8. Keller S., G. Zimmermann 1989. Macopathogen of Siol insects. [In:] Insect-Fungus Interactions. Wilding N., Collins N.M., Hammon P.H., Webber J.F. (Eds.) Acadamic Press, London, 204-270.

9. Kolczarek R., Jankowski K. 2014. Occurrence of entomopathogenic fungi in soils from Festuca pratensis Huds. Crop. J. Ecol. Eng., 15 (2), 73-77.

10. Linden J. 1967. Outline of insect pathology. PWRiL. Warsaw.

11. Miętkiewski R. Tkaczuk C., Badowska-Czubik T. 1992. Entomogenous fungi isolated from strawberry plantation soil infested by Otiorhynchus ovatus L. Annals of Agricultural Sciences Ser. E, $22(1 / 2) 39-46$.

12. Miętkiewski R. Tkaczuk C., Zurek M., Bałazy S. 1991. Occurrence entomopatogenic fungi in soil arable and forest litter. Rocz. Agricultural Sciences. Ser. E, 21 (1/2), 61-68.

13. Müller-Kögler E., Zimmermann G. 1986. Go to Beauveria bassiana von Lebensdauer in kontaminiertem Boden unter Freiland-Und Laboratoriumsbedungungen. Entomophaga, 31, 285-292
14. Skowera B., Puła J. 2004. Extreme pluvio-thermal conditions in the spring on Polish territory in the 1971-2000. Acta Agrophysica, 3(1), 171-177.

15. Strasser H., Forrer A., Schinner F. 1996. Development of media for the selective isolation and maintenance of virulence of Beauveria brongniartii. In: Microbial control of soil dwelling pests. (Eds. TA Jackson and TR Glare), AgResearch, Lincoln, New Zealand, 125-130.

16. Tkaczuk C., Miętkiewski R., 1996, Occurrence of entomopathogenic fungi in different kinds of soil. Rocz. Agricultural Sciences., Series E, 25 (1/2), 44-48.

17. Tkaczuk C. 2008. Occurrence and potential infectious fungal insecticidesin soils and environments agrocenoz seminaturalnych in the agricultural landscape. Treatise No. 94, Ed. University of Podlasie in Siedlce.

18. Vanninen I. 1999. The distribution, ecological fitness and virulence of entomopathogenic fungideuteromycetous In Finland. Ph. D. Thesis, University of Helsinki. 